講義

\title{
電気化学测定法シリーズ 液・液界面イオン移動の電気化学的測定法
}

 \\ Mitsugi SENDA, Tadaaki KaKUTANI \\ and Toshiyuki OSAKAI
}

互いに混り合わない2つの液体閶また㹥電解質溶液閒 の界面（以下，単に油水界面と呼引゙）の電気現象につい ては古くから研究がなされている(たと党ば，文献 1)。 この油水界面でのイオン平衡と界酶電位差との関係は, 液膜型イオン選択性電極の電位を洛皇重要な因子の一 つであり，数多くの研究がある゙、.また油水界面に外部 加電圧をかけると界面張力が変化する現象，いかゆる 油水界面電気毛管現象についても，近年渡辺らのきわめ てすぐれた研究3があり，彼ら注この現象に対し理想分 極性界面の理論に基づいて，明確な説明を与えることに 成功し，またいくつかの興味ある事実を明らかにしてい る. 最近, 油水界面を通る電流 (正味の電荷移動) と界 面電位差との関係についても，この界面の分極性に着目 したポーラログラフィー, ボルタタトリーによる研究 が，イオン移動反応ばかりでなく雪子移動反応について も報告されている(この分野の最近の進歩については既 に紹介しだので参照していただざたい)。このように， 油水界面注, 電気化学, 電気分析化学に扔いて広い意味 での電極界面を提供するものであり，またたとえば，油 相を極端に薄くした場合，一種の修飾電極と考えること ができ，機能性電極開発の分野でも重要性が増すものと 思われる. 本稿では, 油水界面イネン移動反忘の研究に 用いられる種々の電気化学測定法について, 主として著 者らの経験をもとに紹介する.なお, 本稿では, 油水界 面イオン移動の基礎理論および研觉例については, 詳し くふれないが，それらについては，文献 4) を参照して いただきたい.

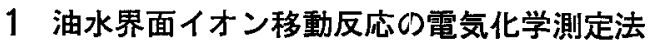

油水界面イオン移動反応の電気仁学測定では, とくに 油相の電気伝尊度が比較的小さいため, 溶液抵抗による 電圧降下 (オーム降下) 功無視できないほど大きくなる ことが多い，このため，界面電位羔を厳密に規制（電位 規制法）または測定 (電流規制法)するために, 通常,

\footnotetext{
* 京都大学農学部 (テ606 京都市左京区北白川追分町)
}

油水両相加ら 2 本の参照電極を用いて界面電位差を規制 または測定する 4 電極方式によって測定される．本節で は，4電極方式による測定に用いられる電解セル，参照 電極, 対極, 装置について述べる.

\section{1 電解セル}

イオン移動反応が生ずる油水界面は, 通常の電極反応 の測定における作動電極に対応し，ここでは作動界面と 呼ぶことにする.これまで用いられてきた作動界面とし て，1）静止油水界面，および 2) 電解質滴下極 (electrolyte dropping electrode) ${ }^{5 \sim 7}$ がある. 後者は, 一方の 電解質溶液を毛細管の先端から他の電解質溶液中に滴下 させるもので, Koryta ら ${ }^{5,6)}$, Samec らりによって油水 界面イオン移動のポーラログラフ測定に用いられてい る.この電解質滴下極は，常に新しい界面で測定できる といら滴下水銀電極と同様な利点をもつと考えられる が，毛細管を使用するため溶液抵抗が大きく，また，そ の見積りも静止界面に比べて困難である，滴下極を用い る場合の電解セルについては, 文献 7) を参照された い.

先に述べたように, 油水界面の場合, 油相の電気伝導 度が一般に低いため溶液抵抗によるオーム降下は, 通常 のポーラログラフィー, ボルタメトリーに比べて大き い. したがって, 電解セルは, 界面電位差の規制または 測定に用いる 2 本の参照電極間の溶液抵抗ができるだけ 小さくなるような, または，その正確な補正が可能な構 造をとることが要求される. 図 1 は，著者らがサイクリ ックボルタメトリー, 電位ステップ法, クロノポテンシ ヨメトリーなどの測定に用いている電解セルである。 こ こで, 静止作動界面は, ガラス管 A内で形成される. 2 つの参照電極液絡用ガラス細管 (ルギン管) 1,2 は, 上 下に動かすことができるようになっている，ルギン管先 端と作動界面間の距離をカセトメータで測定し，マニピ ェレーターを用いてルギン管を上下させると，ルギン管 先端を $0.2 \mathrm{~mm}$ 程度の距離まで正確に作動界面に近づ けることができる．ルギン管先端と作動界面間の距離を オーム降下が無視できるほど小さくするのが望ましいこ 


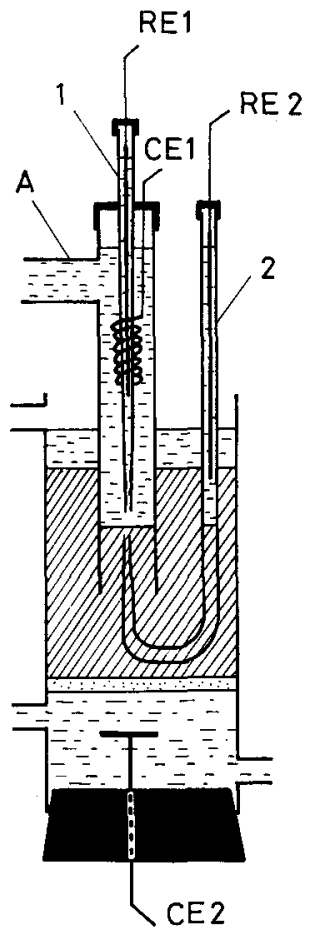

図 1 電解セル

RE 1, RE 2 : 参照電 極, CE 1, CE 2; 対 極, 1,2 参照電極ルギ 管 2-cのようになり，管壁のわずかの污れで界面面積は大

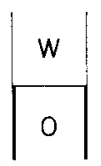

(a)

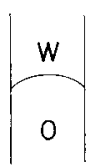

(b)

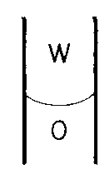

(c)
図 2 静止作動界面の作製法

（a）：油相と接する部分のみシリコン処理した場合

(b):シリコン处理を行なわない愓合

（c）：全体をシリコン処理した場合

きく変動するが，油相と接する部分のみシリコン処理を した場合，図 2-a のような平たんな界面が形成され， 界面面積の再現性は非常によい（その変動は, 数\%以 下).また，このような平たんな界面が形成されると， ルギン管先端と界面間の距離の測定が容易になりつごう がよい.

\section{2 参照電極・対極}

油水界面イオン移動反応の電気化学測定は, 通常, 注 目イオン $\left(\mathrm{B}_{3}\right)$ の他油油 $(\mathrm{O})$ 相和よび水 $(\mathrm{W})$ 相とも
比較的高浱度の支持電解質 $\left(B_{1} A_{1}, B_{2} A_{2}\right)$ を含む采

$$
\alpha\left|B_{1} A_{1}(O)\right| B_{2} A_{2}, B_{3} A_{2}(W) \mid \alpha^{\prime}
$$

で行なわれる*2. このような系に用いる参照電極 $\alpha, \alpha^{\prime}$ は，以下の性能を備えていることが望をしい，1）支持 電解質カチオンまたはアニオンに対して電流ゼ口におけ る電位は可逆でネルンスト式従うこと，2）その電位 は長時間安定であり，再現性があるこ，3）電流が流 れても電位はほとんど变化せず (非分極性)，たとえ変 化してもすぐもとの電位にもどることなどである．ただ し，4電極方式で測定した場合，3）の条件は著しく緩 和される．以下，これ宗で油水界面イオン移動反応の測 定に用いられてきた参照電極の例を紹介するが，とくに 油相の参照電極に対して上記の諸条件が十分検討されて いない場合が多いので，それら使用する際は，少なく とも電位の安定性，再現性については十分チェックする 必要がある.チェックの方法については，本シリーズの 基準電極の章8,9) で述べられているので参照していただ きたい.

油相の溶媒としてニトロベンゼン (NB) を用いた場 合, 溶媒, 支持電解質の項で述べるような理由から，支 持電解質として承相には， $\mathrm{LiCl}$ が，油相にはTBATPB $\left(\mathrm{TBA}^{+}\right.$: テトラブ沃アンモニウムイオン, $\mathrm{TPB}^{-}:$テ トラフェニルボレイトイオン) がよく使用される：

$$
\alpha|\operatorname{TBATPB}(\mathrm{NB})| \mathrm{LiCl}(\mathrm{W}) \mid \alpha^{\prime}
$$

この場合, 水相の渗照電極 $\alpha^{\prime}$ としては, 銀一塩化銀 $(\mathrm{Ag} \mid \mathrm{AgCl})$ 電極, カロメル電極が適当であろう(これ らの電極の性質，作製法，取扱上の注意点などについて は，本シリーズ9でも，また成書 ${ }^{10,12)}$ にも詳細に述べ られているので，艺れらを参照していただきたい). 他 カニトロベンゼン相の参照電極としては，(1)油相との間 に液絡を用いた水滨液用参照電極の利用，(2)イオン選択 性電極の利用，(3)油相の支持電解質と共通イオン種を含 む水溶液用参照電極（以下，油水界面型参照電極 と呼 ぶ) :

$$
\mathrm{e}\left|\mathrm{B}_{1} \mathrm{~A}_{2}(\mathrm{~W})\right| \mathrm{B}_{1} \mathrm{~A}_{1}(\mathrm{O})
$$

の使用にここで $\mathrm{B}_{1}$ が共通イオンで, e は $\mathrm{B}_{1}$ または $\mathrm{A}_{2}$ イオンにネルンスト応答する電極が選ばれる。をとえ ば,（II）の系では, $\mathrm{Ag}|\mathrm{AgCl}| \mathrm{TBACl}(\mathrm{W}) \mid \mathrm{TBATPB}$ (NB) 電極) が考えられる. (1), (2)は非水溶液用の参照 電極としてよく用いられている ${ }^{8)}$. また, Randles ら ${ }^{12)}$ は, ニトロベンゼン水閒のイオンの分配平衡電位差の測 定で，TEAPiの di-isopropylketone 溶液を液絡とした $\mathrm{Hg}|\mathrm{HgPi}| \mathrm{TEAPi}(\mathrm{W}) \mid$ 液絡|電極をニトロベンゼン相 の参照電極にしている (TEA+ : テトラエチルアンモニ ウムイオン, $\mathrm{Pi}^{-}$：ピクレートイオン). 以下, 油水界面 型参照電極 (III) についてやや詳しく述べることにす る.

\footnotetext{
*1 $\mathrm{B}_{8}=\mathrm{B}_{1}$ の系についても行なるれている。
} 
表 1 有機溶媒 $の$ 物 理 的性 質 ${ }^{19)}$

\begin{tabular}{|c|c|c|c|c|c|c|c|}
\hline \multirow{2}{*}{ 溶 } & \multirow{2}{*}{ 比誘電率a) } & \multicolumn{2}{|c|}{ 溶解度 ${ }^{a)}($ 重量 (\%)) } & \multirow{2}{*}{$\left.{ }^{\text {沸 }}{ }^{\circ}\right)^{\text {点 }}$} & \multirow{2}{*}{$\begin{array}{c}\text { 凝固 点 } \\
\left({ }^{\circ} \mathrm{C}\right)\end{array}$} & \multirow{2}{*}{$\begin{array}{l}\left.\text { 密 度 }{ }^{\mathrm{a}}\right) \\
\left(\mathrm{g} c \mathrm{~m}^{-3}\right)\end{array}$} & \multirow{2}{*}{$\begin{array}{c}\text { 粘 度 }{ }^{a)} \\
(c P)\end{array}$} \\
\hline & & in aq. ${ }^{b)}$ & aq. incs & & & & \\
\hline ニトロベンゼン & 3.4 .82 & $0.19_{20}$ & $0.24_{20}$ & 210.8 & 5.76 & 1.1984 & $1.63_{30}$ \\
\hline 1ーニトロプロパン & $23.24_{30}$ & 1.50 & 0.62 & 131.2 & -104.0 & 0.9961 & 0.79 \\
\hline 2-ニトロプロパン & $25.52_{30}$ & 1.71 & 0.53 & 120.3 & -91.3 & 0.9829 & 0.72 \\
\hline 1,2-ジクロロエタン & 10.36 & $0.81_{20}$ & $0.15_{20}$ & 83.5 & -35.7 & 1.2458 & $0.73_{30}$ \\
\hline 4-メチル-2-ペンタノン & $13.11_{20}$ & 1.7 & 1.9 & 116.5 & -84 & 0.7961 & 0.54 \\
\hline ベンゾニトリル & 25.20 & $\sim 0.2$ & $\sim 1_{28}$ & 191.1 & -12.8 & 1.0006 & $1.11_{30}$ \\
\hline ビス（2-クロロエチル)-エーテル & $21.2_{20}$ & $1.02_{20}$ & $0.1_{20}$ & 178.8 & -46.8 & 1.213 & 2.14 \\
\hline oークロロアニリン & 13.4 & 0.876 & $0.56_{18}$ & 208.8 & -1.9 & 1.2078 & 2.92 \\
\hline
\end{tabular}

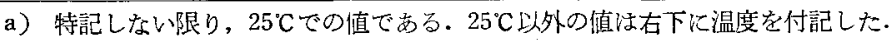

b) 溶媒の水中での溶解度

c）水の溶媒中での溶解度

油水界面型参照電極 (III) では, 枝持電解 質イオン $\mathrm{B}_{\mathrm{t}} ， \mathrm{~A}_{1}$ の内，油相加ら水相への移锄の標準自由エネル ギー変化の小さい方のイオンを共通イオンにする.すな わち, 電極 (III) に扔ける油水界面の電位差が，共通イ オン $\mathrm{B}_{1}$ で，決定されるためには， $\mathrm{B}_{1} ， \mathrm{~A}_{1}$ ，および $\mathrm{A}_{2}$ イオンの水から油相への移動の標準自由エネルギー変化 值 $\triangle G_{\mathrm{tr}, \mathrm{j}}^{0, \mathrm{~W} \rightarrow \mathrm{O}}\left(j=\mathrm{B}_{1}{ }^{+}, \mathrm{A}_{1}{ }^{-}\right.$または $\left.\mathrm{A}_{2}^{-}\right)$間には

$$
\begin{aligned}
& -\triangle G_{\mathrm{tr}, \mathrm{A}_{1}^{-}}^{0, \mathrm{O}_{-}^{-}} \gg 0, \Delta G_{\mathrm{tr}, \mathrm{A}_{2}^{-}}^{0, \mathrm{O}_{-}^{-}} \gg 0 \\
& \left|\triangle G_{\mathrm{tr}, \mathrm{B}_{2}{ }^{+}}^{0, \mathrm{~W}}\right| \ll-\triangle G_{\mathrm{tr}, \mathrm{A}_{-}^{-}}^{0, \mathrm{~W}_{\rightarrow}^{-}} \\
& \left|\triangle G_{\mathrm{tr}, \mathrm{B}_{1}{ }^{+}}^{0, \mathrm{~W}}\right| \ll \Delta G_{\mathrm{tr}, \mathrm{A}_{2}^{-}}^{0, \mathrm{~W} \rightarrow \mathrm{O}}
\end{aligned}
$$

の関係が成立しなければならない：これらの関係が成り 立つとき, 参照電極 (III) の水相 $\left(\mathrm{B}_{1} \mathrm{~A}_{2}\right.$ 溶液) と油相 $\left(\mathrm{B}_{1} \mathrm{~A}\right.$ 溶液) 間のイオン平衡は, ごく少量の $\mathrm{B}_{1}, \mathrm{~A}_{1}$, $\mathrm{A}_{2}$ イオンの移動で達成され，この油水界面の平衡電位 差 $\Delta \varphi\left(\equiv \varphi_{\mathrm{W}}-\varphi_{\mathrm{O}} ; \varphi_{\mathrm{W}}, \varphi_{\mathrm{O}}\right.$ はそれぞれ水相および油相 の内部電位) 注, 非常に良い近似で:

$$
\begin{aligned}
\triangle \varphi \simeq & -\frac{\triangle G_{\mathrm{tr},}^{\mathrm{W}, \mathrm{B}_{1}^{+}}}{z_{\mathrm{B} 1} F} \\
& +\frac{R T}{z_{\mathrm{B}_{1}} F} \ln \frac{a_{\mathrm{B}_{1}}^{0, \mathrm{O}}}{a_{\mathrm{B}_{1}}^{0, W}}
\end{aligned}
$$

で与えられる.ここで $z_{\mathrm{B} 1}$ は $\mathrm{B}_{1}$ イオ ンのイオン価数, $a_{\mathrm{B}_{1}}^{0, \mathrm{O}}$ および $a_{\mathrm{B}_{1}}^{0, \mathrm{~W}}$ 忙そ れぞれ $\mathrm{B}_{1}$ イオンの油祖执よび水相中の 初期濃度に対灾する活量である。奏祭目 的には, $\left|\triangle G_{\mathrm{tr}, \mathrm{A}_{1}}^{0, \mathrm{~W} \rightarrow \mathrm{O}}\right|-\left|\Delta G_{\mathrm{tr}, \mathrm{B}_{1}}^{0, \mathrm{O}}\right| \geq$ $10 \mathrm{~kJ} / \mathrm{mol},\left|\Delta G_{\mathrm{tr}, \mathrm{A}_{2}}^{0, \mathrm{O}}\right|-\left|\Delta G_{\mathrm{tr}, \mathrm{B}_{\mathrm{\iota}}}^{0, \mathrm{~W} \cdot \mathrm{O}}\right|$ $\geq 10 \mathrm{~kJ} / \mathrm{mol}$ で, $a_{\mathrm{B}_{1}}^{0,}{ }^{\circ}$ と $a_{\mathrm{B}_{1}}^{0, \mathrm{~W}}$ とが㥛端 に違わなければ，(4) 式は成立する*2. たとえば，系（II）のニトロベンゼン相

*2ここで注油相と水相の容積があまり違わ ないことを前提としている。
の参照電極として, $\mathrm{Ag}|\mathrm{AgCl}| \operatorname{TBACl}(\mathrm{W}) \mid \mathrm{TBATPB}$ (NB) 電極を使用した場合，表2の值を用いると， $\left|\triangle G_{\mathrm{tr}, \mathrm{Cl}^{-}}^{0, \mathrm{NB}}\right|-\left|\triangle G_{\mathrm{tr}, \mathrm{TBA}}^{0, \mathrm{~W} \rightarrow \mathrm{NB}}\right|=7.4 \mathrm{~kJ} / \mathrm{mol}$, $\left|\triangle G_{\mathrm{tr}, \mathrm{TPB}}^{0, \mathrm{~W} \rightarrow \mathrm{NB}^{-}}\right|-\left|\triangle G_{\mathrm{tr}}^{0, \mathrm{TBA}} \underset{\mathrm{TBA}^{+}}{0 \mathrm{NB}}\right|=11.9 \mathrm{~kJ} / \mathrm{mol}$ となり, $10^{-3} \leq\left(a_{\mathrm{TBA}}^{0, W} / a_{\mathrm{TBA}^{+}}^{0, \mathrm{NB}^{+}}\right) \leq 1$ の範囲で, この参照電極の 油水界面の電位苃は $\mathrm{TBA}^{+}$イオンによって決まる図 3 は，この点をテストした結果の例で,

$$
\begin{aligned}
& \mathrm{Ag}|\mathrm{AgCl}| 0.1 \mathrm{M} \stackrel{\mathrm{I}}{\mathrm{TBACl}}(\mathrm{W}) \mid 0.1 \mathrm{M} \stackrel{\text { II }}{\mathrm{TBATPB}} \\
& \text { (NB) } \underset{\substack{x \mathrm{MT} \mathrm{TBACl} \\
(0.1-x) \mathrm{MLi}+\mathrm{Cl}}}{\text { III }}
\end{aligned}
$$

なる電池（ここで $0.02 \mathrm{M} \leq x \leq 0.1 \mathrm{M}$ ) の起電力 $\varepsilon の$

\begin{tabular}{|c|c|c|c|}
\hline カチオン & $\Delta G_{\mathrm{tr}, \mathrm{j}}^{\mathrm{o}, \mathrm{NB} \rightarrow \mathrm{W}} / \mathrm{kJ} \mathrm{mol} \mathrm{m}^{-1}$ & $r=\pi \nu$ & $\Delta G_{\mathrm{tr}, \mathrm{j}}^{\mathrm{o}, \mathrm{NB} \rightarrow \mathrm{W}} / \mathrm{kJ} \mathrm{mol} \mathrm{m}^{-1}$ \\
\hline $\mathrm{Li}^{+}$ & -38.2 & $\mathrm{Cl}^{-}$ & -31.4 \\
\hline $\mathrm{Na}^{+}$ & -34.3 & $\mathrm{I}^{-}$ & -18.8 \\
\hline $\mathrm{H}^{+}$ & -32.5 & $\mathrm{ClO}_{4}^{-}$ & -8.0 \\
\hline $\mathrm{NH}_{*}^{+}$ & -26.8 & Picrate & 4.6 \\
\hline $\mathrm{K}^{+}$ & -23.4 & $\mathrm{I}_{8}^{-}$ & 23.4 \\
\hline $\mathrm{Rb}^{+}$ & -19.4 & $T B^{-v)}$ & 36.0 \\
\hline $\mathrm{Cs}^{+}$ & -15.4 & Dipicrylaminate & 39.4 \\
\hline $\left.\mathrm{TMA}^{+} \mathrm{i}\right)$ & -3.4 & & \\
\hline $\mathrm{TEA}^{+\mathrm{i} i}$ & 5.7 & & \\
\hline $\mathrm{TBA}^{+i \mathrm{ii})}$ & 24.0 & & \\
\hline TPhAs+iv) & 36.0 & & \\
\hline
\end{tabular}
測定結果である. 起電力 $\varepsilon$ は $\ln \left(C_{\mathrm{TBA}^{+}}^{0, \frac{\pi}{B^{+}}} / C_{\mathrm{TBA}^{+}}^{0, \mathrm{I}}\right)$ ( $C_{\mathrm{TBA}^{+}}^{0, \mathrm{i}} i$ 相中の $\mathrm{TBA}^{+}$イオンの初期濃度)に比例し, また，その傾斜は理論値 $\left(=\frac{R T}{F}\right)$ とほぼ一致してい る.したがって,この Ag|AgCl|TBACl(W)|TBATPB
表 2 種々のイオンのニトロベンゼンから水への移動の 標準自由エネルギー変化 $\left(25^{\circ} \mathrm{C}\right)^{21,24)}$

i) Tetramethylammonium, ii) Tetraethylammonium,

iii) Tetrabutylammonium, iv) Tetraphenylarsonium,

v) Tetraphenylborate 


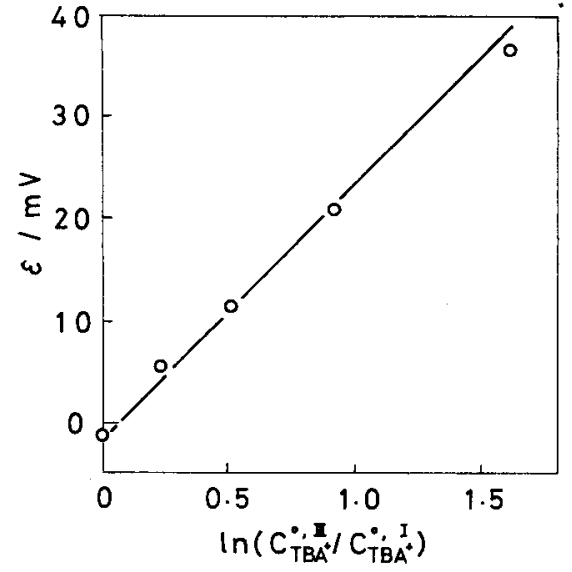

図 3 電池 $(\mathrm{A})$ の起電力 $\varepsilon の \ln \left(\mathrm{C}_{\mathrm{TBA}}^{0,}\right.$, III $\left.C_{\mathrm{TBA}^{+}}^{0, I}\right)$ による変化 ${ }^{13)}$

(NB) 電極のニトロベンゼン水界面の電位差は, $\mathrm{TBA}^{+}$ イオンで決定されているものと考えられる，また，この 電極の電位の再現性は $\pm 5 \mathrm{mV}$ 以内であり，ボルタメ トリー用の参照電極として十分使用できる。

対極として，白金電極，水銀電極などの電極がよく用 いられる。しかし，電位ステップ法や交流分極法を用い て高速の電流応答を測定する場合，このよらな分極性電 極を対極として用いると，とくに油相では対極」溶液界 面の分極インピーダンスは大きくなり，ポテンショスタ ットの応答速度の低下をまねくので注意を要する。実 際，白金対極を直接油相につける方式から，いずれの対 極之も非分極性の $\mathrm{Ag} \mid \mathrm{AgCl}$ 電極を用い $\mathrm{Cl}^{-}$イオンを 含む水溶液中につける方式に変えたところ（図 1)，ポ テンショスタットの応答速度の改善がみられた ${ }^{133}$.

\section{3 電位規制電解法}

ポーラログラフィー，ボルタメトリーなどの電位規制 電解法による測定では，油水界面電位差を厳密に規制す るために油水雨相から 2 本の参照電極を基準にして規制 する 4 電極式ポテンショスタット ${ }^{14-16)}$ を用いる必要が ある．図 4 は，著者らの研究室で用いている回路のブロ ック図で，柳本製 PE 21 型ポテンショスタットを改造 したものである. 別の回路構成も可能である(たとえ ば，文献 17)）。図4の回路に拉いてスイッチを $3 \mathrm{E}$ 側 にすると通常の 3 電極式ポテンショスタットとして動作 し，4E 側にすると 4 電極式ポテンショスタットして動 作する.この 4 電極式回路において，参照電極 RE1の アースに対する電位 $\mathrm{e}_{1}$ は，OA 1 および OA 2 からな る回路によって，常に OA 1 に加えられた入力電圧（規 制電圧）と同じ大きさで対符号の電圧に保たれてい る. 一方, 参照電極 $\mathrm{RE} 2$ の電位 $\mathrm{e}_{2}$ は, OA 3 よって 疑似接地 $\left(\mathrm{e}_{2} \simeq 0\right)$ に保たれている. また参照電極 RE 1, RE 2 は, それぞれ演算増幅器 OA 2 および OA 3 のき

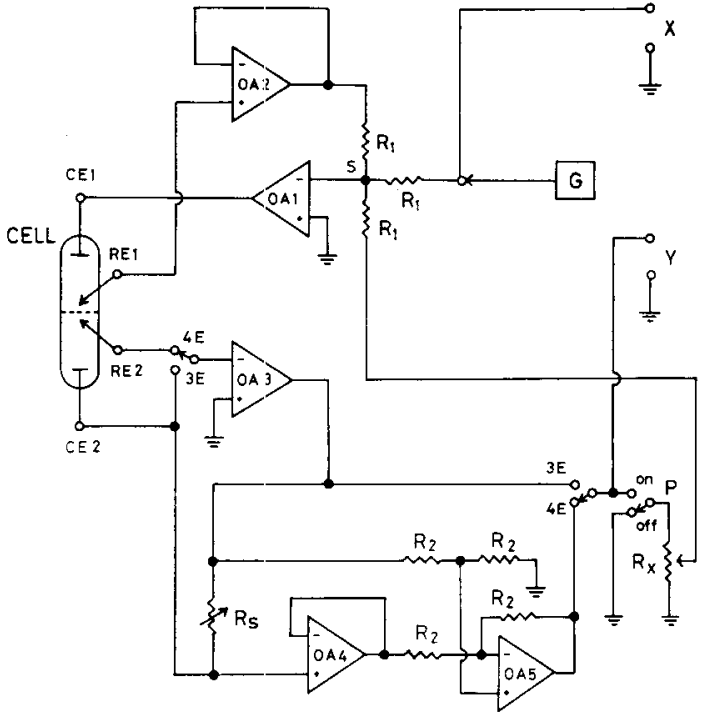

図 44 電㵵式ポテンショスタット ${ }^{(6)}$

わめて高いインピーダンスの大力につながれているの で，RE1，RE 2 を通して流れる電流は無視することが できる．界面に流れる電流は，OA 1 および OA 3 の出 力より対極 CE 1, CE 2 を通して供給され，その值は $\mathrm{CE} 1$ 上 OA 3 の出力との間に㧴入した抵抗 $\mathrm{R}_{\mathrm{s}}$ 間に生 ずる電㾏降下として測定される。また，この回路では， スイッチ $\mathrm{P}$ on にすると，界面に流れる電流に比例し た電圧が $\mathrm{R}_{\mathrm{x}}$ を通して加電圧入力に正帚還されるよう になっており，必要に応じて両参照電極のルギン管先端 閒のオーム降下を補償することができる。しかし，この 正帰還方式によるオーム降下の補償は，装置の不安定化 をまねくなどの問題点 ${ }^{17}$ があり，十分な注意を払って 用いる必要がある。

\section{4 電流規制電解法}

クロノポテンショメトリーなどの電流規制電解法も油 水界面イオン移動反忘の研究に有効である.この場合，

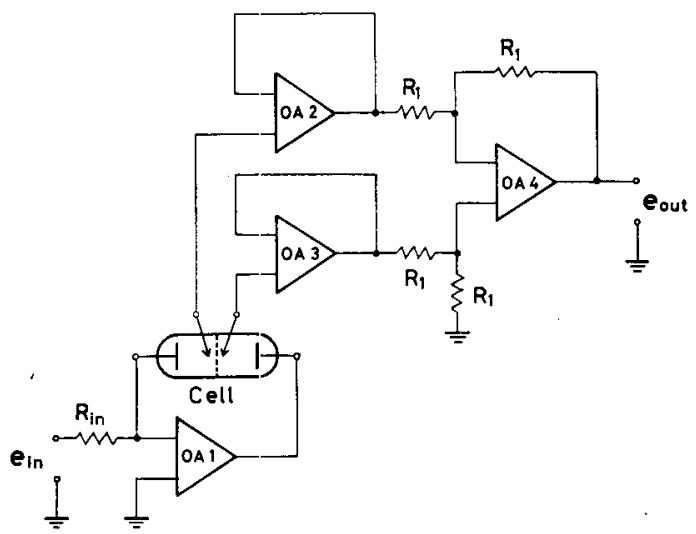

図 5 ガルバノスタット 
通常の電極反応の研筧に用いられるガルバノスタット17 を使用することができる，1例としてて演算増幅器で構成 した最も簢単な回路例を図 5 に示す。この回路では, 電 解セルに流れる電流 $I$ は $I=\mathrm{e}_{\mathrm{in}} / \mathrm{R}_{\mathrm{in}}$ で規制される。 し たがって， $\mathrm{e}_{\mathrm{in}}$ として任意の波形を加えると，電解セル に流れる電流は， $e_{\text {in }}$ に比例した電流 $I$ にって規制さ れる. 油水界面の電位差は，高入力インピーダンスの演 算増幅器 OA 2, OA 3, OA 4 で構成される電位差検出 回路で測定される. Delahay らのブリッジ式回路 ${ }^{18)}$ む, また使用できるであろう。

\section{2 溶媒と支持電唃丝質}

溶媒扝よび支持電解質の選択は, 油水界面イオン移動 反応の電気化学的研究に扎いて, 界面の分極しらる電位 領域愊と関係し4，きわ的て重要である。

油相の溶媒は, 水との相互溶解度が非常に低くて水と 混り合わないという条件のほかに，十分な量の支持電解 質を溶解し，遊離のイオンに解離させる必要があるた め，溶媒の比誘電率は 10 以上であることが望ましい. また，粘度が大きすぎないことも必要である。このよう な制約があるため，これまで報告されている溶媒は，二 トロベンゼンおよび 1,2-ジ夕ロロ江タン限られてい る. そのほか, メチルイソブチルケトン (4-メチル-2ペンタノン） を, 水上の相互溶解度は前述の 2 つの溶媒 に比べてやや大きいが，渡辺ら によって油水界面電気 毛管現象の研究に使用されて抏り，イオン移動の研究に 使用できる可能性のある溶媒の一つであるう．表 1 にこ れらの溶媒も含めて,この種の研究に使用できる可能性 のある溶媒の種々の物理的性質 ${ }^{19}$ 在まとめておいた。

油水界面の分極電位領域は，支持電解質イオンの（水 飽和）油相から（油飽和）水相への溶媒間移動の標準自

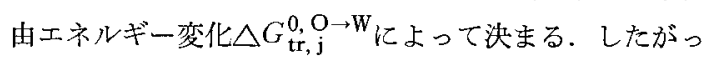
て，油相および水相に用いられる支持電解質は，1）そ れぞれの相に，かなりの程度 (10 $\mathrm{mM}$ 以上) 溶解し， 電解液に十分な電導性を与えること，2）支持電解質イ オンのそれぞれ他相への移動の標準自由エネルギー変化 ができるだけ大きなものが望ましい。こうした理由か ら，たとえば，二トロベンゼン水界面でのイオン移動反 态の研究には，ニトロベンゼン相の支持電解質として TBATPB が，水相の支持電解質として $\mathrm{LiCl}$ がよく用 いられている。この系で界面が実際上分極しているとみ なせる電位領域幅は，約 $0.3 \mathrm{~V}$ である.TBATPBの 代りに, THex ATPB (THex A+ : テトラヘキシルアン モニウムイオン）を，ニトロベンゼン相の支持電解質と して用いる(ニトロベンゼン中の溶解度はTBATPBよ


る ${ }^{13)}$. 水相用の支持電解質として，2 価イオンからなる 塩の使用も考えられるが，現在のとこる十分検討されて
いない.参考までに，Reference electrolyte 仮定 ${ }^{20)}$ を用 いて求めた ${ }^{21,242}$ 種々のイオンの（水飽和）二トロベン ゼンから（二トロベンゼン飽和）水への移動の標準自由

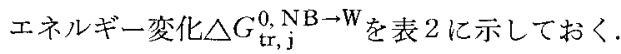

\section{3 油水界面イオン移動のポーラログラフィー およびボルタメトリー}

油水界面イオン移動反応の電気化学的挙動は，金属電 極溶液界面での電荷移動反応の場合と形式上類似してお $り^{4)}$ ，通常の電極反応の研究に用いられてきた種々の電 気化学測定法が適用できる。ここでは，これまで油水界 面イオン移動反态の研究に用いられてきた電気化学測定 法ならびに測定例につマて簡単に紹介する。

\section{1 電解質滴下極 (electrolyte dropping elec- trode）を用いるポーラログラフィー}

Koryta $ら^{5,6)}$, Samec $ら^{7)}$ は, 毛細管の先端より水溶 液をニトロベンゼン溶液中に滴下（水滴が上向きに流出 する）させる電解質滴下極を用いて，油水界面イオン移 動反応のポーラロダラフ測定を行ない，たとえば， 0.5 $\mathrm{mM}$ TMACl, $0.05 \mathrm{M} \mathrm{LiCl}, 1 \mathrm{M} \mathrm{MgSO}{ }_{4}(\mathrm{~W}) \mid 0.05 \mathrm{M}$ $\mathrm{TBATPB}(\mathrm{NB})$ 系 $\left(\mathrm{TMA}^{+}\right.$: テトラメチルアンモニウ ムイオン) について, TMA+イオンの移動に基うく典 型的なポーラログラフ波をえている7.このよらに，滴 下極を用いて油水界面イオン移動の電流-電位曲線の測 定が可能であるが，この場合毛細管を使用するため，溶 液抵抗はかなり高くなり，定量的な解析が可能なポーラ ログラムをえるためには，オーム降下の補償または補正 が不可久である. Samec らり は，口径 $0.3 \mathrm{~mm}$ の毛細 管を用いたとき，上述の電解系で, 参照電極ルギン管先 端閒の溶液抵抗を $10 \mathrm{k} \Omega$ と見積り，これを正帰還回路 (1.3 参照) を用いて補償している.

\section{2 電位ステップ法 ${ }^{22}$}

上述のよらに, 滴下極方式を用いて, 油水界面イオン 移動反応の電流一電位曲線を求めることもできるが，静 止油水界面を用いた電位ステップ法によっても次のよう にして求めることができる22,。すなわら，最初，界面に イオン移動反応が生じない電位差 $E_{\mathrm{i}}$ をかけておき，時 間 $t=0$ で階段状の電位差 $\triangle E=E-E_{\mathrm{i}}$ を与えると, $\triangle E$ の大きさに応じてイオン移動による電流が流机る. 一定時閒 $t=t_{\mathrm{s}}$ 後の電流值 $I_{\mathrm{t}=\mathrm{t}_{\mathrm{s}}}$ を $E$ に対してプロッ トすると, 電流一電位曲線がえられる. また, 非常に短 時間内の電流忘答から速度論的研究も行ならことができ る.

図 $6^{22)}$ は, $0.5 \mathrm{mM} \mathrm{TMABr}, 0.1 \mathrm{M} \mathrm{LiCl}(W) / 0.1$ M TBATPB(NB) 系について図1 で示したセルを用い て測定した TMA+ イオンの水相からニトロベンゼン相 への移動による電流-時間曲線である。この結果は，油 相および水相の参照電極のルギン管先端をそれぞれ界面 


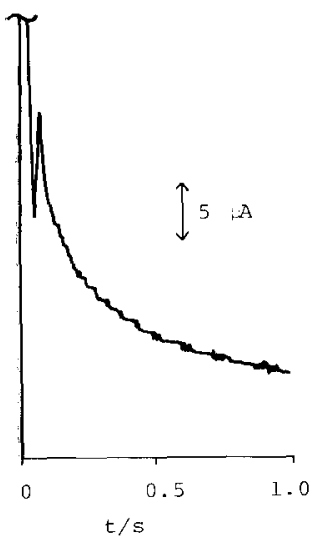

図 $6 \mathrm{TMA}^{+}$の電流-時 間曲線 ${ }^{22}$

$0.5 \mathrm{mM}$ TMABr, $0.1 \mathrm{M}$ $\mathrm{LiCl}$ (水) $10.1 \mathrm{M}$ TBA TPB（ニトロベンゼン） 系, $E=0.380 \mathrm{~V}, E_{\mathrm{i}}=$ $0.200 \mathrm{~V}$

半波電位注次式で定義される.

$E_{\mathrm{l} / 2, \mathrm{j}}=\triangle \phi_{1 / 2, \mathbf{j}}+$ const.

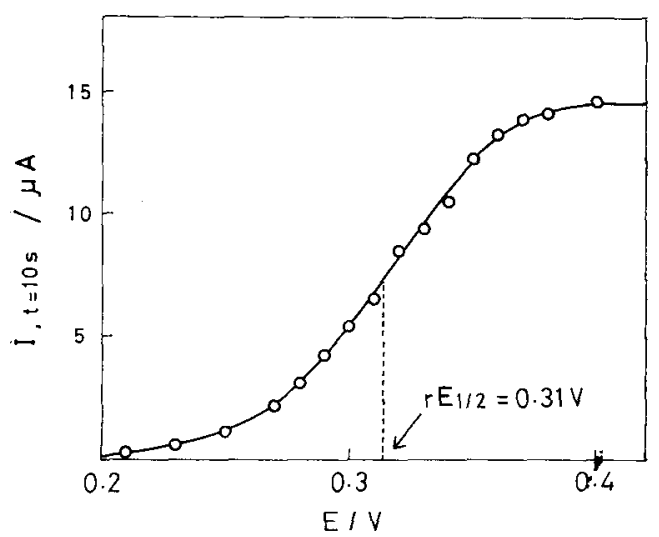

図 7 電位ステップ法による $\mathrm{TMA}^{+}$の電流-電位 曲線 ${ }^{22}$

$1 \mathrm{mM}$ TMABr, $0.1 \mathrm{M} \mathrm{LiCl}$ (水) $\mid 0.1 \mathrm{M}$ TBATPB (ニトロベンゼン) 䒺, $t_{\mathrm{s}}=10 \mathrm{~s}$

表 3 種々の電気化学測定法で測定した $\mathrm{TMA}^{+}$ イオンのニトロベンゼン水界面イオン移 動の半波電位と抬散係数 ${ }^{13,16,22)}$

\begin{tabular}{c|c|c}
\hline \multicolumn{1}{c|}{ 方 } & $E_{1 / 2}{ }^{a}(\mathrm{~V})$ & $D^{\mathrm{w}}\left(\mathrm{cm}^{2} \mathrm{~s}^{-1}\right)$ \\
\hline 電位ステップ法 & 0.31 & $1.3 \times 10^{-5}$ \\
サイクリックボルタメトリー & 0.32 & $1.3 \times 10^{-5}$ \\
クロノポテンショメトリー & 0.32 & $1.2 \times 10^{-5}$ \\
\hline
\end{tabular}

a) 浿定系: $\mathrm{Ag}|\mathrm{AgCl}| 0.1 \mathrm{M} \operatorname{TBACl}(\mathrm{W}) \mid 0.1 \mathrm{M}$ TBATPB(NB) $10.5-2 \mathrm{mM}$ TMABr, $0.1 \mathrm{M} \mathrm{LiCl}(\mathrm{W}) ! \mathrm{AgCl} \mid \mathrm{Ag}$

$$
\begin{aligned}
\triangle \phi_{1 / 2, j} & =-\frac{\Delta G_{\mathrm{tr}, \mathrm{O}}^{0, \mathrm{O} \rightarrow \mathrm{W}}}{z_{\mathrm{j}} F}- \\
& +\frac{R T}{z_{\mathrm{j}} F} \ln \frac{r^{\mathrm{O}} \sqrt{D^{\mathrm{W}}}}{\gamma^{\mathrm{W}} \sqrt{D^{\mathrm{O}}}}
\end{aligned}
$$

ここで, $r^{\mathrm{i}}, D^{\mathrm{i}}$ は $i$ 相 $(i=\mathrm{O}, \mathrm{W})$ 中でのイオン $j の$ 活量係数括よび桩散係数である. const. は，使用した参 照電極の電位に関係した量で一定である。この方法で は，静止界面を用いているので，ルギン管先端間の溶液 抵抗をかなり小さくすることができ，また，その值の見 積りも比較的容易に行なえる。さらに， $t_{\mathrm{s}}$ 適当に設定 すれば，オーム降下の無視できる条件下で電流-電位曲 線を求めることもできる。

\section{3 サイクリックボルタメトリー}

油水界面に三角波電圧を加えるサイクリックボルタメ トリー法も，油水界面イオン移動反応の有力な研究法の 一つである

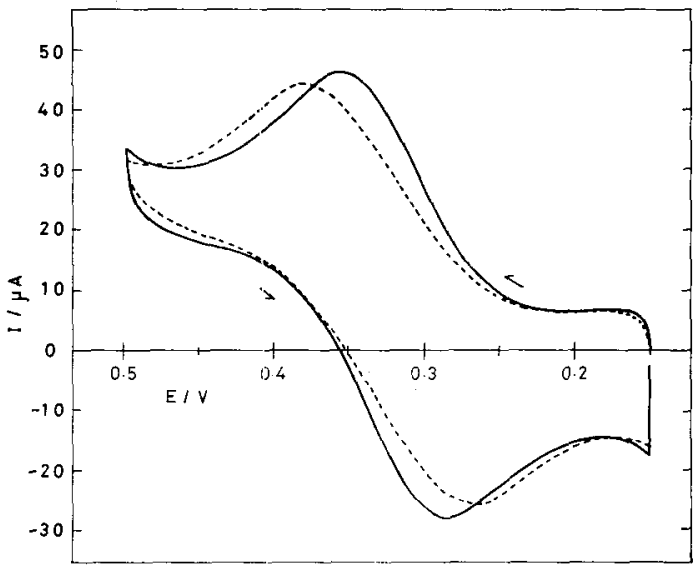

図 $8 \mathrm{TMA}^{+}$のサイクリックボルタモグラム ${ }^{16)}$ $2 \mathrm{mM}$ TMA.Br, $0.1 \mathrm{M} \mathrm{LiCl}$ (水) $\mid 0.1 \mathrm{M}$ TBA$\mathrm{TPB}($ ニトッベンゼン) 系, 電l锓引速度 $: 20 \mathrm{~m}$ $\mathrm{Vs}^{-1}$, 実線: $d_{\mathrm{N}}=0.2 \mathrm{~mm}, d_{\mathrm{W}}=1.0 \mathrm{~mm}$, 破線： $d_{\mathrm{N}}=d_{\mathrm{W}}=1.0 \mathrm{~mm}$

(W) [0.1 M TBATFB(NB) 系のサイクリックボルタ モグラムである.ここで正電流ピークは $\mathrm{TMA}^{+}$イオン の水からニトロベンジンへの移動に対応し, 負電流ピー クはニトロベンゼンタら水への移動に対空する。また， 実線は, 界面から油相抒よひ水相の参照電極ルギン管先 端との距離 $d_{\mathrm{N}}, d_{\mathrm{W}}$ 艺それぞれ $0.2 \mathrm{~mm}$ 拉よび $1.0 \mathrm{~mm}$ にしてえたボルタモグラムで，破線は， $d_{\mathrm{N}}=d_{\mathrm{W}}=1.0$ $\mathrm{mm}$ にしたときのボルタモグラムである。このようにボ ルタモグラムの波形, とくにピーク電位は, 参照電極ル ギン管先端の位置に看しく依存寸るので， $d_{\mathrm{N}}, d_{\mathrm{W}}$ を正 確汇設定する必要が㣌る。図 9 は，前述の系で， $d_{\mathrm{W}}=$ $1.0 \mathrm{~mm}$ に固定し， $d_{\mathrm{N}}$ を変化させてえたボルタモグラ ムのピーク電位を $d_{\mathrm{N}}$ に対してプロットした結果であ る. 正電流ピークおよび負電流ピークのピーク電位 $E_{\mathrm{p}}$ 


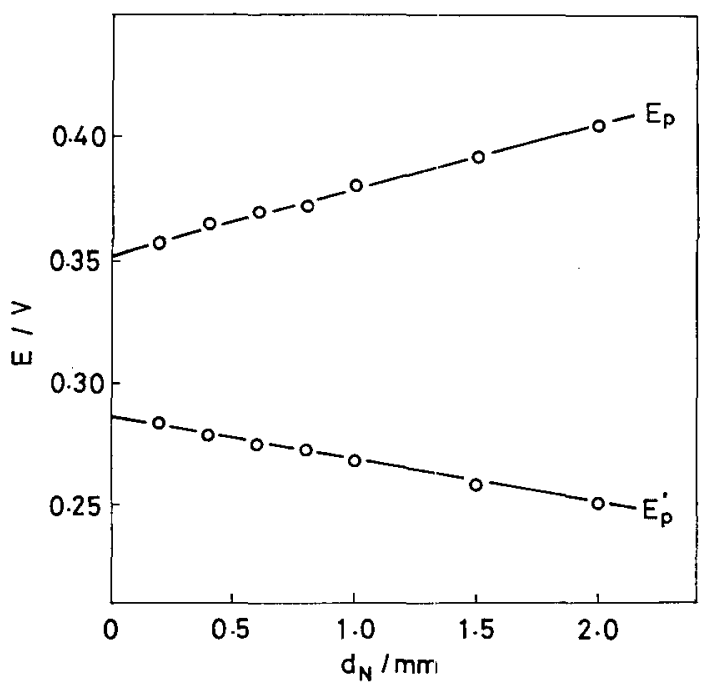

図 $9 \mathrm{TMA}^{+}$のサイクリックボルタモダラムの ピーク電位の $d_{\mathrm{N}}$ による変化 ${ }^{16)}$

$2 \mathrm{mM}$ TMABr, $0.1 \mathrm{M} \mathrm{LiCl}$ (水) $\mid 0.1 \mathrm{M}$ TBATPB (二トロベンゼン) 系, 電位接引速度 : $20 \mathrm{mVs}^{-1}, d_{\mathrm{W}}$ $=1.0 \mathrm{~mm}$

および $E_{\mathrm{p}}{ }^{\prime}$ は，いずれも $d_{\mathrm{N}}$ に対こて直線的に変化して おりまた，これらの直線の傾斜はニトロベンゼン溶液 の電気伀導度から見積った值とよく一致している.した がって， $d_{\mathrm{N}}$ および $d_{\mathrm{W}}$ をに外雨することにより，オー ム降下を補正した $E_{\mathrm{p}}, E_{\mathrm{p}}{ }^{\prime}$ およで $\triangle E_{\mathrm{p}}\left(\equiv\left|E_{\mathrm{p}}-E_{\mathrm{p}}{ }^{\prime}\right|\right)$ を求めることができる．TMA+ ’オンの場合，このよ 5にして求めた $\triangle E_{\mathrm{p}}$ は $0.06 \mathrm{~V}$ 上なり，宗たピーク電 流值は, 水相中の $\mathrm{TMA}^{+}$イオンの濃度並びに電圧掃引 速度の平方根に比例しており，可逆波の理論で説明され ることがわかる 一法で求めた $\mathrm{TMA}^{+}$イオンの半波電位および $D^{\mathrm{W}}$ が 示されている、いずれも，他の測定法でえられた結果と

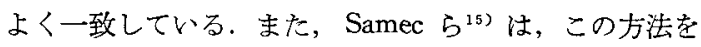
用いて，二トロベンゼン水界面での $\mathrm{Cs}^{+}$イオンの移動 の速度論的パラメータを求めている.

\section{4 クロノポテンショメトリー.}

油水界面に強制的に一定電流を流し，そのとき生ずる 界面電位差の時間変化を測定する：いわゆるクロノポテ ンショメトリー法も, 油水界面イオン移動反忘の研究法 として有効である. 図 10 は, $2 \mathrm{mM} \mathrm{TMABr}, 0.1 \mathrm{M}$ $\mathrm{LiCl}(\mathrm{W}) \mid 0.1 \mathrm{M}$ TBATPB (NB) 系について測定した $\mathrm{TMA}^{+}$イオンの水から二トロベンゼンへの移動のクロ ノポテンショグラムである ${ }^{13)}$. 遷移時間の平方根は, 電 流密度に反比例し, 四分波電位 $E_{\mathrm{r} / 4}$ は，電位ステップ 法またはサイクリックボルタメトリー法でえた半波電位 の值とよく一致している（表 3 ). また, Gavach ら $ら^{232}$ は，この方法を用いて，一連のテトラアルキルアンモニ

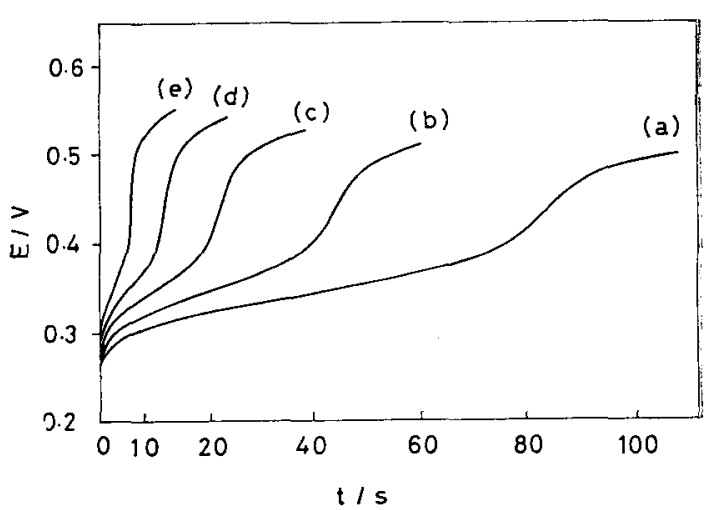

図 $10 \mathrm{TMA}^{+}$のクロノポテショメトリー電位-時 間曲線 ${ }^{13}$ )

$2 \mathrm{mM}$ TMABr, $0.1 \mathrm{M} \mathrm{LiCl}$ (水) $10.1 \mathrm{M}$ TBA. TPB（ニトロベンゼン）悉, 電流密度 : (a) 63, (b) 94 , (c) 126 , (d) 189 , (e) $252 \mu \mathrm{A} \mathrm{cm}^{-2}$

ウムイオンのニトロベンゼン水界面での移動反応の速度 論的研究を行なっている.

これまで油水界面イオン移動反応の研究に用いられて きた電気化学測定法について簡単に紹介してきたが，上 記以外に交流分極法の適用が可能であるう. 現在のとこ ろ油水界面イオン移動反応の測定法として確立するに至 っていない22)が，この方法は，とくに速度論的な研究 に有效であろらと思われる。

以上, 油水界面イオン移動反心種々の電気化学測定 法について，その実験法を中心に紹介した. 今後, こう した油水界面の電位差と界面電荷移動反応の関係に着目 した電気化学的研究は, 種々の分析化学的灾用の面ばか りでなぐ，生体膜抢よびそのモデル系（人工 2 分子膜 系, リポソーム系並びにエマルジョン系など) での反応 の理解においてもその重要性が増すむのと思われる. た,このような油水界面イオン移動の電気化学測定法 は, 単イオンの溶媒間移動の標準自由エネルギー変化

(の相対値)を測定する方法の一つとしても期待され る. 本稿が，こうした油水界面および関連領域の研究発 展の一助ともなれば幸いである。

\section{文献}

1) W. Nernst and E.H. Riesenfeld, Ann. Physik 8, 600 (1902); J.T. Davies and E.K. Rideal, "Interfacial Phenomena", Academic Press, New York, 1961.

2) J. Koryta, "Ion-selective electrodes", CambridgeUniversity Press, London, 1975.

3) 渡辺 昌, 日化誌 92, 575 (1971) 渡辺 晶, 玉井久子, 表面 13，67 (1975)。

4）千田 貢, 角谷忠昭, 表面 18,535 (1980).

5) J. Koryta, P. Vanysek and M. Brezina, J. Electroanal. Chem. 67, 265 (1976).

6) J. Koryta, P. Vanysek and M. Brezina, J. Electroanal. Chem. 75, 211 (1977).

7) Z. Samec, V. Marecek, J. Weber and D. Homolka, 
J. Electroanal. Chem. 99, 385 (1979).

8) 伊豆津公佑, 中村俊夫, 電気化学 48,78 (1980).

9) 大滝仁志, 前田益伸, 電気化学 48, 278 (1980).

10) R.G. Bates, "Electrometric pH Determinations", John Wiley \& Sons, New York, 1954.

11) D.J.G. Ives and G.J. Janz, "Reference Electrodes", Academic Press, NewYork, 1961.

12) F.M. Karpfen and J.E.B. Randles, Trans. Faraday Soc. 49, 823 (1953).

13）著者ら, 未発表.

14) Z. Samec, V. Marecek, J. Koryta and M.W. Khalil, J. Elctroanal. Chem. 83, 393 (1977).

15) Z. Samec, V. Marecek and J. Weber, J. Electroanal. Chem. 100, 841 (1979).

16) 千田貢, 角谷忠昭, 大堺利行, 分析化学討論会, 1980 .

17) 高橋勝緒, 電気化学 49, 2 (1981).

18) P. Delahay, in Delahay and Tobias (ed.), "Advances in Electrochemistry and Electrochemical
Engineering”, Vol. 1, pp. 233 318 (1961), Interscience Pub., N.Y.

19) J.A. Riddick and W.B. Bunger, "Organic Solvents", (Techniques of Chemistry, Vol. II), 3 rd. ed. WileyInerscience, 1970.

20) E. Grunwald, G. Baughman and G. Kohnstam, $J$. Amer. Chem. Soc. 82, 5801 (1960).

21) J. Rais, Collect. Czeck, Chem. Commum. 36, 3253 (1971).

22) T. Kakutani, T. Osakai and M. Senda, Paper presented at the Polarographic meeting, Oct. 14-15, 1980, Fukuoka; abstract, Rev. Polarogr. (Kyoto) 26, 24 (1980); 投稿準備中.

23) B. D'Epenous;, P. Seta, G. Amblard and C. Gavach., J. Electroanal. Chem. 99, 77 (1979).

24) J. Rais, P. Selucky and M. Kyrs, J. Inorg. Nucl. Chem. 38, 1376 (1976).

\section{基硌電気化学についての文献紹介（2）}

“酸素発生反応”についての論文を, Electrochim. Acta Vol. 26-No. 1〜4 (1981) および J. Electroanal. Chem. Vol. 117-No. 1, 2 (1981), Vol. 119-No. 1, 2 (1981）の中から拾ってみた. なお，J. Electrochem. Soc. Vol. 128-No. 1〜3 (1981) にはこの種の論文はな W.

(2-1) "Kinetics and mechanism of anodic chlorine and oxygen evolution reactions on transition metal oxide electrodes"; L.I. Krishtalik, Electrochim. Acta 26, 329 (1981): $\mathrm{RuO}_{2}$ 電極を用いた陽極酸化における， 塩素あるいは酸素発生の反応機構を論じている. 電極と しては, この他, $\mathrm{RuO}_{2}-\mathrm{TiO}_{2}, \mathrm{MNi}(\mathrm{Co}) \mathrm{O}_{3}, \mathrm{M}_{2} \mathrm{Re}_{2} \mathrm{O}_{7}$, $\mathrm{MCO}_{2} \mathrm{O}_{4}$, や $\mathrm{MCr}_{2} \mathrm{O}_{4}$ も用いられている。

(2-2) "Oxygen evolution reaction on transition metal borides"; T. Osaka, H. Ishibashi, T. Endo and T. Yoshida, Electrochim. Acta 26, 339 (1981): ほう
素と金属の組成比定変化させた種々の遷移金属ほう化物 の酸素発生反応に扔ける活性を比較し，次のよ5な系列 を見いだしている;

$$
\mathrm{Ni}_{x} \mathrm{~B} \simeq \mathrm{Co}_{x} \mathrm{~B} \gg \mathrm{Fe}_{x} \mathrm{~B}>\mathrm{LaB}_{6}>\mathrm{Co} \simeq \mathrm{Fe}>\mathrm{Ni}
$$

(2-3) "The anodic evolution of oxygen and chlorine on foreigrı metal doped $\mathrm{SnO}_{2}$ film electrodes"; C. Iwakura, M. Inai, T. Uemura and H. Tamura, Electrochim. Acta 26, 579 (1981): Sb, Ru, Rh, Pd, $\mathrm{Ir}, \mathrm{Pt}$ などをドープした $\mathrm{SnO}_{2}$ 電極における，酸素お よび塩素発生反応の性質を，電極物質の他の物理的ある い注化学的性質と比較して論じている。

$O$ (2-4) "Oxygen gas evolution on hydrous oxides - an example of three-dimentional electrocatalysis?"; L.D. Burke and E.J.M. O'Sullivan, J. Electroanal. Chem. 117, 155 (1981): (Preliminary note).

(理化学研究所 高橋勝緒) 